\title{
Anthropometric Parameter That Best Predicts the Relationship Between Obesity and Osteoporosis in Kidney Transplant Recipients
}

\author{
Böbrek Nakilli Hastalarda Obezite ve Osteoporoz Arasındaki ilişskiyi En lyi Tahmin Eden \\ Antropometrik Parametre \\ (1D Sadiye Murat, (1) Gülşah Şaşak* \\ istanbul Medeniyet University, Göztepe Training and Research Hospital, Clinic of Physical Medicine and Rehabilitation, Istanbul, Turkey \\ *istanbul Medeniyet University, Göztepe Training and Research Hospital, Clinic of Nephrology, İstanbul, Turkey
}

\section{Abstract}

Objective: This study aimed to investigate the relationship between obesity and osteoporosis in kidney transplant recipients (KTRs) using a body shape index (ABSI), a new anthropometric measurement parameter.

Materials and Methods: In this cross-sectional study, a total of 130 KTRs were included. Laboratory and demographic findings, aetiology of kidney failure, time on dialysis, donor type, time after transplantation, additional diseases, menopausal status for women and medications were recorded from patients' files. Height, weight and waist and hip circumferences were also recorded from the files. ABSI was calculated using a specific formula. Bone mineral density (BMD) was measured using dual X-ray absorptiometry. Patients were divided into the following three groups based on the T-score: Normal, osteopenia and osteoporosis groups, according to the World Health Organization recommendations.

Results: According to the BMD values, 24 patients (18.5\%) had normal BMD, 82 patients (63.1\%) were osteopenic and 24 patients (18.5\%) were osteoporotic. Patients with osteoporosis have significantly higher parathormone hormone and ABSI and lower body mass index (BMI) than patients without osteoporosis $(p<0.05)$. A positive correlation of BMI was found in the lumbar $(r=0.294, p=0.002)$ and femoral T-scores $(r=0.216, p=0.024)$. A negative correlation was found between $A B S I$ and lumbar $T$-score $(r=-0.237, p=0.014)$. Receiver operating characteristic curves showed that ABSI had the optimal power to discriminate patients with/without osteoporosis in both sexes.

Conclusion: $A B S I$ is found to be a more useful tool than anthropometric measurements in predicting osteoporosis in KTRs.

Keywords: ABSI, renal transplant, osteoporosis, obesity

\section{Öz}

Amaç: Böbrek nakilli hastalarda obezite ile osteoporoz arasındaki ilişkiyi yeni bir antropometrik ölçüm olan "beden şekil indeksi (ABSI)" kullanarak araştırmayı amaçladık.

Gereç ve Yöntem: Bu kesitsel çalışmaya, takip edilen 130 böbrek nakilli hasta alındı. Laboratuvar ve demografik bulgular, böbrek yetersizliği etiyolojisi, diyaliz süresi, donör tipi, nakil sonrası süre, ek hastalıklar, kadınlarda menopoz durumu, ilaçlar hasta dosyalarından kaydedildi. Boy, kilo, bel ve kalça çevresi de dosyalardan kaydedildi. ABSI, belirli bir formülle hesaplandı. Kemik mineral yoğunluğu (KMY), dual X-ışını absorpsiyometrisi kullanılarak ölçüldü. T-skoruna göre hastalar normal, osteopenik ve osteoporotik olarak üç gruba ayrıldı.

Bulgular: KMY değerlerine göre 24 hasta $(\% 18,5)$, normal 82 hasta $(\% 63,1)$ osteopenik ve 24 hastada $(\% 18,5)$ osteoporotikti. Vücut kitle indeksi ile lomber $(r=0,294, p=0,002)$ ve femur T-skorları ile arasında pozitif korelasyon bulundu $(r=0,216 p=0,024)$. Lomber T-skoru ile ABSI arasında negatif korelasyon bulundu $(r=-0,237, p=0,014)$. ROC eğrileri, ABSI'nın her iki cinsiyette osteoporozu olan ve olmayan hastaları ayırt etmek için en uygun güce sahip olduğunu gösterdi.

Sonuç: ABSI'nın, böbrek nakilli hastalarda osteoporozu tahmin etmede diğer antropometrik ölçümlere kıyasla daha değerli olduğu bulundu. Anahtar kelimeler: ABSI, böbrek nakli, osteoporoz, obezite

Address for Correspondence/Yazışma Adresi: Sadiye Murat MD, İstanbul Medeniyet University, Göztepe Training and Research Hospital, Clinic of Physical Medicine and Rehabilitation, İstanbul, Turkey

Phone: +90 5327313046 E-mail: samurftr@gmail.com ORCID ID: orcid.org/0000-0002-6544-7095

Received/Geliş Tarihi: 22.12.2019 Accepted/Kabul Tarihi: 16.04.2020

${ }^{\circ}$ Copyright 2021 by the Turkish Osteoporosis Society / Turkish Journal of Osteoporosis published by Galenos Publishing House. 


\section{Introduction}

Kidney transplantation is the gold standard method for the treatment of end-stage renal failure. The increase in graft survival is associated with various complications. Among these, osteoporosis and low-energy fractures are important causes of morbidity and mortality $(1,2)$.

Pathogenesis of transplant related osteoporosis is complex and multifactorial. Immunosuppressive agents and immobilization play the main role (3). Weight gain is often observed after kidney transplantation. Although some studies showed that the high body mass index (BMI) is high bone mineral density (BMD), the others claimed that obesity could increase the likelihood of osteoporosis $(4,5)$. Obesity is an inflammatory condition. Obese patients have higher levels of IL- 6 and TNF- $\alpha$ proinflammatory cytokines in their blood. This proinflammatory milieu can cause osteoclast activation $(6,7)$.

Computed tomography (CT), magnetic resonance imaging (MRI), and dual energy X-ray absorptiometry (DXA) can accurately assess body fat composition. These methods are expensive and their use in the routine clinical setting are difficult. Different methods are used to evaluate obesity [e.g BMI, waist circumference (WC), hip circumference $(\mathrm{HC})$, waist to hip ratio $(\mathrm{WHR})$, and waist to height ratio $(\mathrm{WHtR})]$. All these anthropometric measurements have some limitations. BMI cannot differentiate fat mass (FM) from muscle mass and peripheral fat from abdominal fat $(8,9)$. Krakauer and Krakauer (10) developed a new method, "A body shape index $(A B S I)$ ", to identify abdominal obesity. Several studies reported that $A B S I$ is independently associated with, metabolic syndrome, diabetes, hypertension (11-13). ABSI is independently associated with a higher mortality rate compared to other anthropometric measures $(10,14)$.

In this study, we investigated the relationship between obesity and osteoporosis in kidney transplant recipients (KTRs) using a new anthropometric measurement "ABSI".

\section{Materials and Methods}

All KTRs who were followed up in our clinic were evaluated to be included in the study. The inclusion criteria were as follows: Patients had to have a renal transplant for more than one year, with stable renal function and stable immunosuppressive regimen during the last 6 months. Patients aged younger than 18 years were excluded.

Laboratory and demographic findings regarding age, sex, smoking status, etiology of kidney failure, time on dialysis, donor type, time after transplantation, additional diseases, menopausal status for women, drugs, glucose, urea, creatinine, 25-hydroxyvitamin D, parathormone (PTH), calcium, phosphorus, C-reactive protein (CRP), sedimentation, lipid parameters, were recorded from electronic data bases. Patients' blood pressure, WC and HC, height, weight were also recorded from the files. $A B S I$ was calculated with the following formula: ABSI: WC $(\mathrm{cm}) /\left[B M 1^{2 / 3} \times\right.$ height $\left.(\mathrm{m})^{1 / 2}\right]$.
BMD was measured using DXA. Measurements of the T-score of the spine at the level of L1-L4 and left femoral neck were estimated. Patients were divided into three groups based on T-score according to the definitions recommended by the World Health Organization (WHO). The results were categorized as T>1.0 normal, $T \leq 2.5-1.0$ as osteopenia and $T<2.5$ as osteoporosis according to $\mathrm{WHO}$ diagnostic criteria. Patients were divided into three groups based on BMD values. Group 1 consisted of patients BMD values were normal, group 2 were osteopenic, group 3 were osteoporotic.

The local ethics committee approved the study protocol (decision no: 2018/0231, date: 15.08.2018). Written informed consent was taken from all subjects before enrolment.

\section{Statistical Analysis}

Statistical analyses were performed with SPSS (version 15.0, SPSS Inc, Chicago, IL). The data were expressed as the mean \pm standard deviation. The distribution of the variance was analyzed with the Kolmogorov-Smirnov test. The relationship between categorical variables was assessed by the chi-square test. Differences between parametric variables of the two groups were assessed by Student's t-test or Mann-Whitney U test, whichever is appropriate. Partial Spearman correlation coefficients were used to assess the association between anthropometric and biochemical measurements after adjustment for age and sex. To assess the ability of anthropometric measures to discriminate between patients who have or not have osteoporosis, receiveroperating characteristic (ROC) curve analysis was done. A p-value below 0.05 was considered statistically significant. Posthoc power analysis was calculated using MedCalc for Windows, version 15,0 (mEDCALC Software, Ostend, Belgium).

\section{Results}

One hundred and thirty patients were included in the study. Of the 130 patients, 90 (69.2\%) were male and 40 (30.8\%) were female. The mean age of the patients was $48.9 \pm 11.5$ years. The number of patients who underwent cadaveric kidney transplantation was 34 (26.2\%), and the number of patients undergoing living-related kidney transplantation was 96 (73.8\%). When the post-hoc sample size was calculated with 0.05 type 1 error, -0.237 correlation coefficient, 137 were detected.

According to BMD values, 24 patients (18.5\%) had normal BMD values, 82 patients (63.1\%) were osteopenic and 24 patients (18.5\%) were osteoporotic. Patients were divided into two groups based on sex. Eight (20\%) of the female patients have normal BMD values, 24 (60\%) were osteopenic, 8 (20\%) were osteoporotic. In men, $16(17.5 \%)$ of the patients had normal BMD values and 58 (64.4\%) were osteopenic, 16 (17.5\%) were osteoporotic.

Demographic and laboratory characteristics of the groups are shown in Table 1.

Patients with osteoporosis have significantly higher PTH and ABSI and they have lower BMI than patients without osteoporosis $(p<0.05)$. 
Table 2 shows the results of partial Spearman correlation coefficients of femoral and lumbar T-scores along with biochemical and anthropometric measurements after adjustment for age and sex. There was a positive correlation of BMI with the lumbar $(r=0.294, p=0.002)$, and femoral T-scores $(r=0.216 p=0.024)$. A negative correlation was found between $A B S I$ and lumbar T-score $(r=-0,237, p=0.014)$ (Table 2).

ROC curves showed that ABSI had the optimal power to discriminate patients with or without osteoporosis in both sexes (Figures 1, 2).

\section{Discussion}

In this presented study, we compared the associations between five anthropometric indices (ABSI, BMI, WC, WHR, WHtR) and osteoporosis in KTRs. According to our results, ABSI have better predictive power for predicting osteoporosis than any other anthropometric measures.

Osteoporosis is a skeletal disorder characterized by compromised bone strength. It is characterized by reduced osteoblast proliferation, accelerated osteoclastogenesis, and impaired bone mineralization process that can result in deterioration of trabecular and cortical thickness and density (15). The prevalence of osteoporosis is high in KTRs. The pathophysiology of bone and mineral metabolism in the post-transplant period is complex. Osteoporosis in KTRs is not only caused by uremic osteodystrophy but also caused by risk factors such as age, gender, persistent hyperparathyroidism, vitamin D deficiency, physical inactivity, tobacco, and alcohol use, steroids and immunosuppressive agents (16). The prevalence of high calcium, low phosphorus and/or high PTH before transplantation should be assessed and, if necessary, correction of axial disorders of the calcium-PTH-D vitamin is mandatory (15). Evaluation of post-transplant calcium and PTH levels can identify patients with high fracture risk due to hyperparathyroidism (17). Renal failure is associated with PTHinduced bone-mineral disease following renal transplantation (18). High PTH levels cause a high risk of fracture in obese patients, especially in areas where cortical bone is dense (19). In this study, we found lower mean T-scores with high PTH levels compared to that with lower PTH levels $(p=0.006)$. Previous studies have shown no correlation between serum creatinine, calcium, phosphorus, alkaline phosphatase, vitamin D levels, and BMD outcomes $(18,20)$. Our study results were similar $(p>0.05)$. We think that our standardized follow-up and treatment protocol for KTRs before and after transplantation may have affected this result. Optimal patient adherence to follow-up had also an important impact.

The role of glucocorticoids in the development of osteoporosis in KTRs in the first 6 months after transplantation is already known. The high-dose steroid use in the early period disrupts the activity of osteoblasts and suppresses bone formation. In the

Table 1. Demographic and laboratory characteristics of patients

\begin{tabular}{|c|c|c|c|c|}
\hline & Osteoporosis & Osteopenia & Normal & $\mathbf{p}$ \\
\hline Age (years) & $44.6 \pm 10.6$ & $49.9 \pm 11.8$ & $50.4 \pm 9.98$ & 0.107 \\
\hline Male/female & $16-8$ & $58-24$ & $16-8$ & 0.889 \\
\hline Type of donor/cadaveric living & $9-15$ & $17-65$ & 8-16 & 0.175 \\
\hline Serum calcium (mg/dL) & $9.5 \pm 0.6$ & $9.7 \pm 0.5$ & $9.9 \pm 0.6$ & 0.082 \\
\hline Serum phosphorus (mg/dL) & $3.25 \pm 0.6$ & $3.5 \pm 0.65$ & $3.5 \pm 0.98$ & 0.351 \\
\hline Vitamin D (ng/mL) & $18.9 \pm 13.7$ & $18.6 \pm 14.0$ & $14.0 \pm 6.7$ & 0.428 \\
\hline PTH $(p g / m L)$ & $139 \pm 88$ & $94.8 \pm 61.8$ & $69.7 \pm 38.2$ & $0.006^{*}$ \\
\hline $\mathrm{CRP}(\mathrm{mg} / \mathrm{dL})$ & $0.93 \pm 1.1$ & $0.7 \pm 1.01$ & $0.69 \pm 1.19$ & 0.243 \\
\hline $\operatorname{ESR}(\mathrm{mm} / \mathrm{h})$ & $23.3 \pm 23.4$ & $27.9 \pm 24.5$ & $29.2 \pm 26$ & 0.737 \\
\hline TG & $138.9 \pm 73.4$ & $159.8 \pm 105$ & $185.7 \pm 149.2$ & 0.704 \\
\hline $\mathrm{HDL}$ & $46.7 \pm 12.4$ & $47.7 \pm 16.5$ & $47.3 \pm 12.3$ & 0.962 \\
\hline LDL & $113.7 \pm 39.2$ & $121.5 \pm 36.3$ & $131.8 \pm 27.5$ & 0.286 \\
\hline TC & $188.2 \pm 48.5$ & $200.4 \pm 49$ & $217.9 \pm 48.1$ & 0.179 \\
\hline Medicines (fk/cyc/evo) & $17-6-1$ & $48-26-8$ & $19-4-1$ & 0.377 \\
\hline Smoke & 3 & 11 & 5 & 0.630 \\
\hline BMI $\left(\mathrm{kg} / \mathrm{m}^{2}\right)$ & $23.7 \pm 4.2$ & $27.3 \pm 4.8$ & $27.3 \pm 6.08$ & $0.007^{*}$ \\
\hline $\operatorname{ABSI}\left(\mathrm{m}^{11 / 6} \mathrm{~kg}^{-2 / 3}\right)$ & $0.0891 \pm 0.00$ & $0.0857 \pm 0.0$ & $0.0869 \pm 0.00$ & $0.027^{*}$ \\
\hline$W C(\mathrm{~cm})$ & $97.4 \pm 9.99$ & $99.9 \pm 12.1$ & $100.9 \pm 13.9$ & 0.079 \\
\hline WHR & $0.90 \pm 0.18$ & $0.96 \pm 0.9$ & $0.96 \pm 0.07$ & 0.287 \\
\hline WHtR & $0.58 \pm 0.06$ & $0.6 \pm 0.07$ & $0.6 \pm 0.09$ & 0.164 \\
\hline
\end{tabular}

PTH: Parathormone, BMI: Body mass index, CRP: C-reactive protein, ESR: Erythrocyte sedimentation rate, TG: Triglyceride, HDL: High-density lipoprotein, LDL: Low-density lipoprotein, TC: Total cholesterol, ABSI: A body shape index, WC: Waist circumference, WHR: Waist to hip ratio, WHtR: Waist t height ratio, * $p<0.05$ 
later stages of kidney transplantation, reduction in the dose of corticosteroids may ameliorate osteoblast functions, reduction of bone loss and improvement in bone density (21). In our study, no statistically significant correlation was found between the steroid dose and the femur and lumbar T-score ( $p=0.377)$.

The prevalence of obesity is an important problem in KTRs (22). The results of studies on the relationship between obesity and osteoporosis are contradictory.

In studies conducted in different patient groups, high BMI has been shown to have a positive effect on $\operatorname{BMD}(6,23)$. In a study in which 1,126 patients were evaluated for abdominal FM and fracture risk, women with high abdominal FM had a lower risk of fractures (24). When the relationship between BMI and BMD was evaluated in KTRs, Sezer et al. (20) found a positive

Table 2. Partial correlation analysis between parameters and anthropometric indices and lomber-femoral T-scores

\begin{tabular}{|l|l|l|l|l|}
\hline \multirow{2}{*}{} & \multicolumn{2}{|c|}{ L1-L4 } & \multicolumn{2}{c|}{ Femur neck } \\
\cline { 2 - 5 } & R & p & r & p \\
\hline BMI $\left(\mathrm{kg} / \mathrm{m}^{2}\right)$ & 0.294 & $0.002^{*}$ & 0.216 & $0.024^{*}$ \\
\hline ABSI $\left(\mathrm{m}^{11 / 6} \mathrm{~kg}^{-2 / 3}\right)$ & -0.237 & $0.014^{*}$ & -0.013 & 0.896 \\
\hline WC $(\mathrm{cm})$ & 0.229 & $0.617^{\star}$ & 0.235 & $0.064^{*}$ \\
\hline WHR & 0.015 & 0.880 & 0.083 & 0.394 \\
\hline WHtR & 0.079 & 0.106 & 0.045 & 0.106 \\
\hline
\end{tabular}

ABSI: A body shape index, WC: Waist circumference, WHR: Waist to hip ratio, WHtR: Waist t height ratio, ${ }^{*} p<0.05$

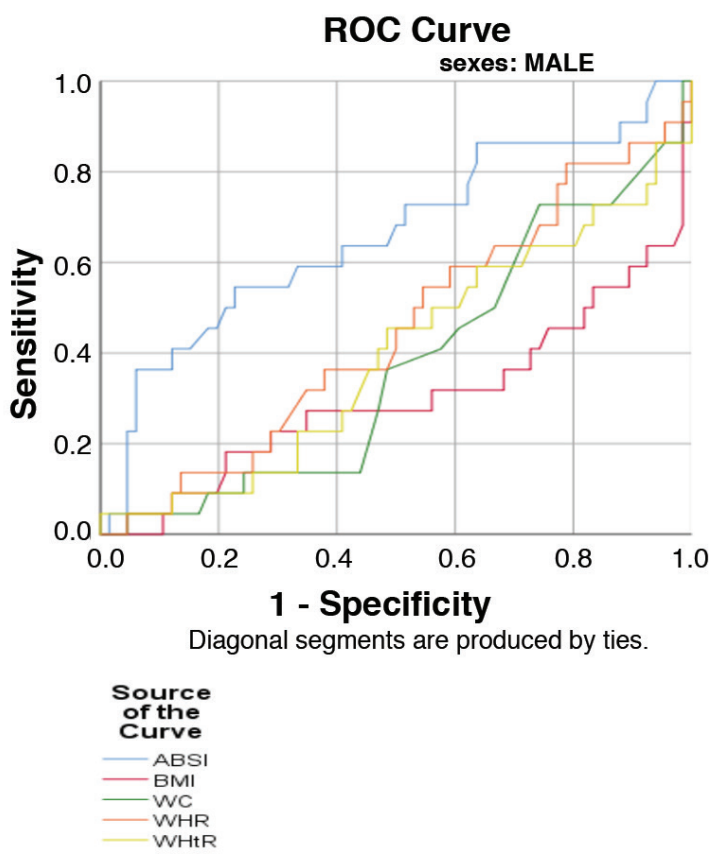

Figure 1. Receiver-operating characteristic curves for anthropometric measure to predict osteoporosis in men

ROC: Receiver-operating characteristic, ABSI: A body shape index, WC: Waist circumference, WHR: Waist to hip ratio, WHtR: Waist t height ratio, BMI: Body mass index correlation between BMI and BMD. On the other hand, recent studies shown that obesity and osteoporosis have common pathophysiological mechanisms. Contrary to the previous results, they suggested that obesity can cause osteoporosis $(4,25,26)$. Kim et al. (27) found that body fat and WC was negatively correlated with BMD. In our study, we also found a positive correlation between $\mathrm{BMI}$ and $\mathrm{BMD}$ and a negative correlation between $A B S I$ and BMD. We did not find any relation between WC and BMD. WC does not take height into account, therefore it may underestimate visceral fat in short populations. These results indicate that $\mathrm{BMI}$ alone is not sufficient in determining fracture risk factors and that obesity assessment methods need to be reviewed again (28). CT, MRI, DXA can be used to accurately measure body fat composition. These methods are expensive and their use in the routine clinical setting are difficult. For these reasons, anthropometric measurements are commonly used in clinical practice.

Studies based on ABSI, a relatively new method, are still emerging and mostly based on cancer and cardiovascular mortality $(8,10,11,28)$. Although there are few studies showing the relationship between $\mathrm{ABSI}$ and osteoporosis, negative correlations were found in studies performed in men over 50 and in women with postmenopausal osteoporosis $(29,30)$. In the literature, there were no studies evaluating the relationship between ABSI and osteoporosis in KTRs. In our study, lumbar

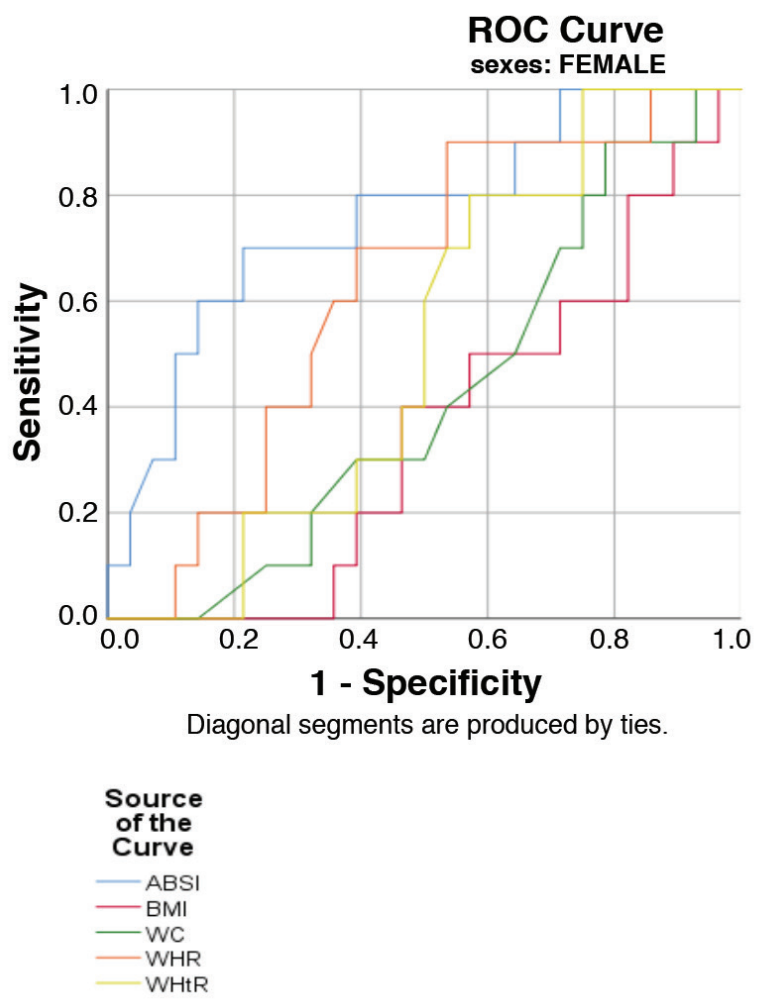

Figure 2. Receiver-operating characteristic curves for anthropometric measure to predict osteoporosis in women

ROC: Receiver-operating characteristic, ABSI: A body shape index, WC: Waist circumference, WHR: Waist to hip ratio, WHtR: Waist t height ratio, BMI: Body mass index 
vertebra T-scores were found to be low in the high ABSI group and high $A B S I$ may increase the risk of vertebral fractures in the renal KTRs.

CRP levels are higher in obese subjects. The elevation of CRP also results in an increase in serum bone turnover markers, a decrease in BMD and a higher risk of bone fracture (6). In our study, no significant relationship was found between CRP elevation, $A B S I$ and $B M D$ values $(p=0.243)$. Immunosuppressive treatment may have a negative effect on these results.

When we examined the relationship between BMD and livingrelated and cadaveric kidney transplantation, no statistically significant relationship was found between BMD and the type of donor $(p=0.175)(31)$.

\section{Study Limitations}

The main limitations of our study were the relatively small patient sample and the use of cross-sectional study design. Our patients were heterogeneous in terms of factors such as age, duration of renal failure and dialysis, time after transplantation, number of rejection episodes, menopausal status in women and immunosuppressive medications used.

\section{Conclusion}

Osteoporosis is more prevalent among patients with KTRs and associated with increased mortality and morbidity in this group. Therapy options were limited as bisphosphonates are not recommended in KTRs because of their adverse side effects. Obesity is one of the most important risk factors for developing osteoporosis. There is a clinical benefit in showing relationship of obesity and osteoporosis in KTRs. It is especially important to establish an accurate and precise diagnosis of obesity. According to our results, ABSI was a more useful tool to predict osteoporosis in KTRs, compared to anthropometric measurements. There is a need for more extensive studies to justify good predictors of osteoporosis in this special set of patients.

\section{Ethics}

Ethics Committee Approval: The İstanbul Medeniyet University, Göztepe Training and Research Hospital Clinical Research Ethics Committee approved the study protocol (decision no: 2018/0231, date: 15.08.2018).

Informed Consent: Written informed consent was taken from all subjects before enrolment.

Peer-review: Externally and internally peer-reviewed.

\section{Authorship Contributions}

Concept: S.M., G.Ş., Design: S.M., G.Ş., Data Collection or Processing: S.M., G.Ş., Analysis or Interpretation: S.M., G.Ş., Writing: S.M.

Conflict of Interest: No conflict of interest was declared by the authors.

Financial Disclosure: The authors declared that this study received no financial support.

\section{References}

1. Damasiewicz MJ, Ebeling PR. Management of mineral and bone disorders in renal transplant recipients. Nephrology (Carlton) 2017;22(Suppl 2):65-9.

2. Lan $G B$, Xie XB, Peng LK, Liu L, Song L, Dai HL. Current status of research on osteoporosis after solid organ transplantation: pathogenesis and management. Biomed Res Int 2015;2015:413169.

3. Małgorzewicz S, Wołoszyk P, Chamienia A, Jankowska M, Dębska-Ślizień A. Obesity risk factors in patients after kidney transplantation. Transplant Proc 2018;50:1786-9.

4. Premaor MO, Pilbrow L, Tonkin C, Parker RA, Compston J. Obesity and fractures in postmenopausal women. J Bone Miner Res 2010;25:292-7.

5. Compston J. Obesity and fractures in postmenopausal women. Curr Opin Rheumatol 2015;27:414-9.

6. Cao JJ. Effects of obesity on bone metabolism. J Orthop Surg Res 2011;6:30.

7. Greco EA, Lenzi A, Migliaccio S. The obesity of bone. Ther Adv Endocrinol Metab 2015;6:273-86.

8. Bigaard J, Frederiksen K, Tjønneland A, Thomsen BL, Overvad $\mathrm{K}$, Heitmann BL, et al. Body fat and fat-free mass and all-cause mortality. Obes Res 2004;12:1042-9.

9. Ruhl CE, Everhart JE. Trunk fat is associated with increased serum levels of alanine aminotransferase in the United States. Gastroenterology 2010;138:1346-56.

10. Krakauer NY, Krakauer JC. A new body shape index predicts mortality hazard independently of body mass index. PLoS One 2012;7:39504.

11. He S, Chen X. Could the new body shape index predict the new onset of diabetes mellitus in the Chinese population? PLoS One 2013;8:50573.

12. Matsha TE, Hassan MS, Hon GM, Soita DJ, Kengne AP, Erasmus RT. Derivation and validation of a waist circumference optimal cutoff for diagnosing metabolic syndrome in a South African mixed ancestry population. Int J Cardiol 2013;168:2954-5.

13. Duncan MJ, Mota J, Vale S, Santos MP, Ribeiro JC. Associations between body mass index, waist circumference and body shape index with resting blood pressure in Portuguese adolescents. Ann Hum Biol 2013;40:163-7.

14. Krakauer NY, Krakauer JC. Dynamic association of mortality hazard with body shape. PLoS One 2014;9:88793.

15. Gosmanova EO, Gosmanov AR. Osteoporosis in patients with diabetes after kidney transplantation. Rev Endocr Metab Disord 2017;18:97-106.

16. Alis G, Alis M, Erturk T, Karayagiz AH, Berber I, Cakir U. Evaluation of bone disease in kidney transplant recipients. Transplant Proc 2017:49:509-11.

17. Perrin P, Caillard S, Javier RM, Braun L, Heibel F, Borni-Duval C, et al. Persistent hyperparathyroidism is a major risk factor for fractures in the five years after kidney transplantation. Am J Transplant 2013:13:2653-63

18. Karataş A, Erdem E, Kaya C, Dilek M, Yakupoğlu YK, Özden E, et al. Risk Factors for Osteoporosis in Renal Transplant Recipients. Turk J Nephrol 2012;21:267-72.

19. Sukumar D, Schlussel Y, Riedt CS, Gordon C, Stahl T, Shapses SA. Obesity alters cortical and trabecular bone density and geometry in women. Osteoporos Int 2011;22:635-45.

20. Sezer S, Ozdemir FN, Ibis A, Sayin B, Haberal M. Risk factors for osteoporosis in young renal transplant recipients. Transplant Proc 2005;37:3116-8.

21. Hardinger KL, Koch MJ, Brennan DC. Current and future immunosuppressive strategies in renal transplantation. Pharmacotherapy 2004;24:1159-76.

22. Grosso G, Corona D, Mistretta A, Zerbo D, Sinagra N, Giaquinta $A$, et al. The role of obesity in kidney transplantation outcome. Transplant Proc 2012;44:1864-8.

23. Holecki M, Zahorska-Markiewicz B, Chudek J, Wiecek A. Changes in bone mineral density and bone turnover markers in obese women 
after short-term weight loss therapy during a 5-year follow-up. Pol Arch Med Wewn 2010;120:248-54.

24. Yang S, Nguyen ND, Center JR, Eisman JA, Nguyen TV. Association between abdominal obesity and fracture risk: a prospective study. J Clin Endocrinol Metab 2013;98:2478-83.

25. Caffarelli C, Alessi C, Nuti R, Gonnelli S. Divergent effects of obesity on fragility fractures. Clin Interv Aging 2014;9:1629-36.

26. Pollock NK, Laing EM, Baile CA, Hamrick MW, Hall DB, Lewis RD. Is adiposity advantageous for bone strength? A peripheral quantitative computed tomography study in late adolescent females. Am J Clin Nutr 2007;86:1530-8.

27. Kim KC, Shin DH, Lee SY, Im JA, Lee DC. Relation between obesity and bone mineral density and vertebral fractures in Korean postmenopausal women. Yonsei Med J 2010;51:857-63.
28. Dhana K, Kavousi M, Ikram MA, Tiemeier HW, Hofman A, Franco $\mathrm{OH}$. Body shape index in comparison with other anthropometric measures in prediction of total and cause-specific mortality. J Epidemiol Community Health 2016;70:90-6.

29. Qin K, He M, Cao XT, Yang HW, Yang Y, Wang YJ, et al. Obesity and osteoporosis in men aged above 50. Sichuan Da Xue Xue Bao Yi Xue Ban 2017;48:17-22.

30. An K, Qin K, Li SY, Yang HW, Wu QQ, Huang Y, et al. Obesity and bone mineral density in menopausal women. Sichuan Da Xue Xue Bao Yi Xue Ban 2017;48:23-7.

31. Unal A, Kocyigit I, Sipahioglu MH, Tokgoz B, Kavuncuoglu F, Oymak $\mathrm{O}$, et al. Loss of bone mineral density in renal transplantation recipients. Transplant Proc 2010;42:3550-3. 